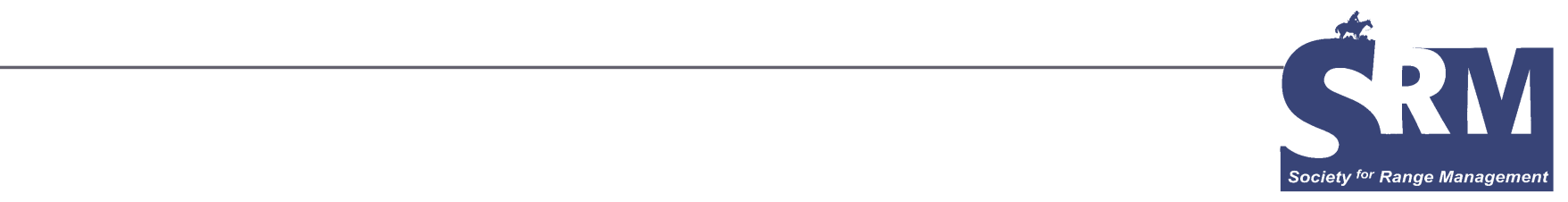

\title{
Sculpting Brush Mechanically: Current State of the Art
}

\section{By Harold T. Wiedemann}

Editor's Notes: Information in this article was previously published in Brush Management: Past, Present, and Future, Texas AE'M University Press, College Station, Texas, p. 33-46. Additional information about these and other types of equipment used on rangeland is described in the Revegetation Equipment Catalog available at http://reveg-catalog.tamu.edu.

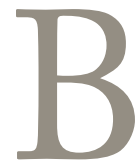

rush-dominated rangelands occur over vast areas of Texas that were previously dominated by grasses. Coping with excessive tree and shrub cover has been a costly and often futile activity of ranchers for several decades. Historically, brush was viewed only as a nuisance to livestock production, and brush eradication was the prevailing management paradigm of many ranchers throughout the 1950s. Large-scale broadcast mechanical or chemical methods were applied over entire pastures or ranches. Maintenance of brush control and proper grazing management were not utilized; hence, many programs failed.

In the 1960s, it became apparent that brush eradication was neither physically possible nor economically feasible, so brush control became the prevailing philosophy. Management goals continued to be total eradication of targeted woody plants. Around 1975, the phrase "brush management" became more popular and reflected the idea that some woody plants had value. Wildlife in Texas was becoming more important as an economic entity during this time. In addition, environmentalists were starting to

Mention of a trade name is for identification only and does not imply an endorsement. call for a reduction in herbicide use. During the 1980s, stakeholders began to realize the value of addressing resource management practices simultaneously. This led to the development of integrated brush management. ${ }^{1}$

Range scientists, resource management agencies, and landowners are now recognizing that woody plants have both tangible and intrinsic values. This recognition, smallersized land holdings, and various other reasons, have brought about the current paradigm of brush sculpting. Brush sculpting is a concept in which brush-infested rangeland is sculpted for multiple uses, including wildlife and endangered species habitat, watershed management, recreation, and landscape enhancement, as well as traditional livestock grazing. ${ }^{2}$ These factors have influenced current mechanical brush control methods and devices in many ways. Each will be discussed.

\section{Selective Thinning}

Individual tree treatment is accomplished by grubbing or clipping and is an ideal method for sculpting brush-infested land. Sculpting can involve practices such as leaving islands of brush with connecting corridors to provide a safe habitat for wildlife and a protected pathway for their movement between sites, while cleared areas provide plants for grazing. Grubbing consists of belowground severing while clipping consists of aboveground severing. Grubbing equipment will be discussed first.

Mechanical grubbing is the severing of tree roots below ground by a sharp, U-shaped blade mounted on a tractor (Fig. 1). Tractors can be crawlers, wheel loaders (Fig. 2), or farm-type (Fig. 3) depending on the size of trees to be 


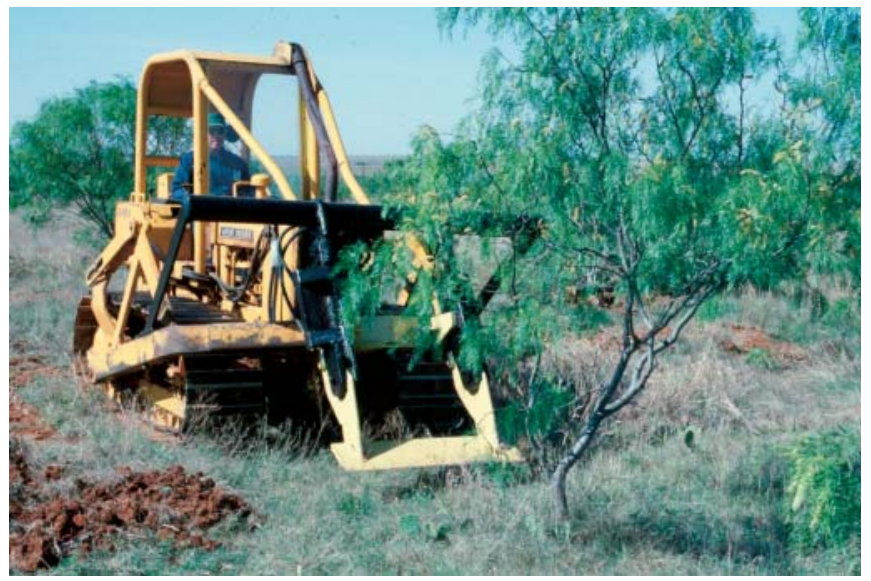

Figure 1. Low-energy grubber. ${ }^{6}$

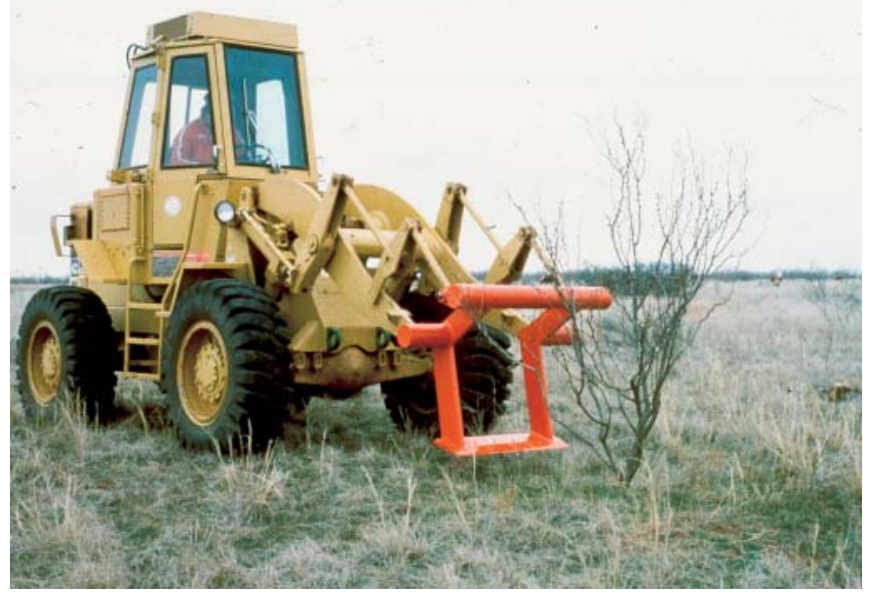

Figure 2. Wheel-loader grubber. ${ }^{4}$

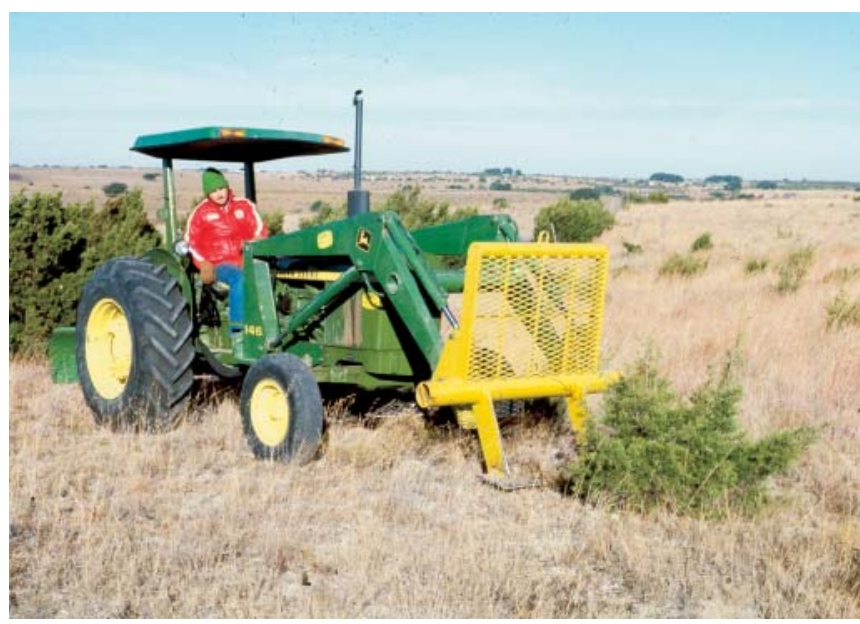

Figure 3. Farm-tractor grubber. ${ }^{4}$

grubbed and the type of terrain. Table 1 describes the best grubbing technique to achieve good plant root kills for various brush species in Texas. (A list of scientific names is provided in the appendix.)

\section{Table 1. Mechanical techniques to prevent the regrowth of 9 different brush species*}

\begin{tabular}{|c|c|}
\hline Species & Technique \\
\hline Mesquite & $\begin{array}{l}\text { Sever taproot below basal crown } \\
\text { (below bud zone), } 6-14 \text { inches deep, } \\
\text { depending on size of tree }\end{array}$ \\
\hline $\begin{array}{l}\text { Redberry } \\
\text { juniper }\end{array}$ & $\begin{array}{l}\text { Sever taproot below basal crown, } \\
6-12 \text { inches deep, depending on size } \\
\text { of tree }\end{array}$ \\
\hline $\begin{array}{l}\text { Ashe } \\
\text { (Blueberry) } \\
\text { juniper }\end{array}$ & $\begin{array}{l}\text { Sever trunk above or below ground } \\
\text { level, does not sprout from roots or } \\
\text { basal crown }\end{array}$ \\
\hline Algerita & $\begin{array}{l}\text { Remove basal crown and buried stems } \\
\text { under entire canopy area, } 4-6 \text { inches } \\
\text { depth }\end{array}$ \\
\hline Huisache & $\begin{array}{l}\text { Sever taproot below basal crown, } \\
6-12 \text { inches deep, depending on size } \\
\text { of tree }\end{array}$ \\
\hline $\begin{array}{l}\text { Twisted } \\
\text { acacia }\end{array}$ & $\begin{array}{l}\text { Remove as many as possible; sprouts } \\
\text { from roots }\end{array}$ \\
\hline Blackbrush & $\begin{array}{l}\text { Sever taproot below second lateral, } \\
6-12 \text { inches deep, depending on size } \\
\text { of tree }\end{array}$ \\
\hline Whitebrush & $\begin{array}{l}\text { Remove basal crown at depth of } 4-6 \\
\text { inches }\end{array}$ \\
\hline Catclaw & $\begin{array}{l}\text { Sever taproot below first lateral and } \\
\text { remove all buried stems with } \\
\text { adventitious roots }\end{array}$ \\
\hline
\end{tabular}

\section{Low-Energy Grubbing}

Low-energy grubbing uses a small tractor on small trees. This can be effective and cost efficient if tree densities are not too high. ${ }^{3}$ These tractors usually have hydraulically assisted blades that enhance performance by tearing roots loose as the blade is rotated. Table 2 presents the performance of a 65-horsepower crawler tractor with a hydraulicassisted blade (Fig. 1) grubbing 7 different brush species. Performance curves are shown in Figure 4. Grubbing rates vary due to tree size, density, distribution, soil moisture, and type of terrain. Grubbing is best suited to tree infestations of 25-250 trees $\cdot$ acre $^{-1}$.

Research involving the use of hydraulic force to assist in uprooting trees was started in the early 1970 s. $^{3}$ Supplementing tree-uprooting forces with hydraulics allowed smaller, less costly tractors to be utilized. The result was the low-energy grubber. Tractor sales and grubber construction averaged over $\$ 1$ million $\cdot \mathrm{yr}^{-1}$ for 5 years in the late 1970s. The concept of hydraulic assistance has spawned a niche industry in Texas that markets novel grubbers for small tractors. 
Table 2. Efficacy of the low-energy grubber (Fig. 1) operating in 7 different brush species*

\begin{tabular}{|c|c|c|c|}
\hline Species & $\begin{array}{c}\% \text { plant } \\
\text { kill }\end{array}$ & Trees $\cdot$ acre $^{-1}$ & Dollars $\cdot$ acre $^{-1 * *}$ \\
\hline Mesquite & 80 & $20-100$ & $3.00-12.00$ \\
\hline Juniper & 98 & $30-175$ & $4.50-27.00$ \\
\hline Huisache & 75 & $75-225$ & $9.50-30.00$ \\
\hline Algerita & 93 & $15-80$ & $5.50-16.50$ \\
\hline $\begin{array}{l}\text { Twisted } \\
\text { acacia }\end{array}$ & 0 & $30-250$ & $3.50-16.00$ \\
\hline Blackbrush & 86 & $20-130$ & $6.50-19.00$ \\
\hline Catclaw & 85 & $50-150$ & $8.50-20.50$ \\
\hline
\end{tabular}

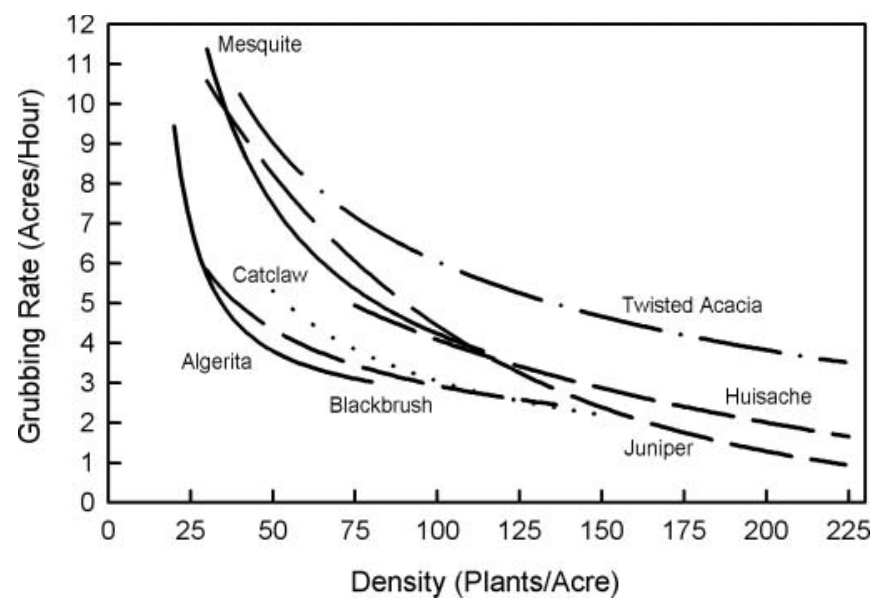

Figure 4. Performance curves for a 65-horsepower crawler tractor grubbing 7 brush species. A field-efficiency factor of $70 \%-85 \%$ should be anticipated.

\section{Loaders}

With the advent of foam filling of off-road tires, the use of rubber-tired equipment on thorn-infested rangeland became practical. ${ }^{4}$ Wheeled loaders are especially useful for grubbing (Fig. 2) because they provide excellent vision for the operator, they can travel on roads between sites, and the bucket can be useful for material-handling jobs. Crawler tractors have to be hauled between sites. Performance of a wheeled loader in mesquite (Prosopis glandulosa var. glandulosa) regrowth 10 years following rootplowing is shown in Figure 5. In a grubbing comparison between a loader (Fig. 2) and crawler tractor of equal size ( 80 horsepower), the loader had 38\% less soil disturbance and $43 \%$ less fuel consumption than the crawler. Productivity of the loader was the same as the crawler at a density of

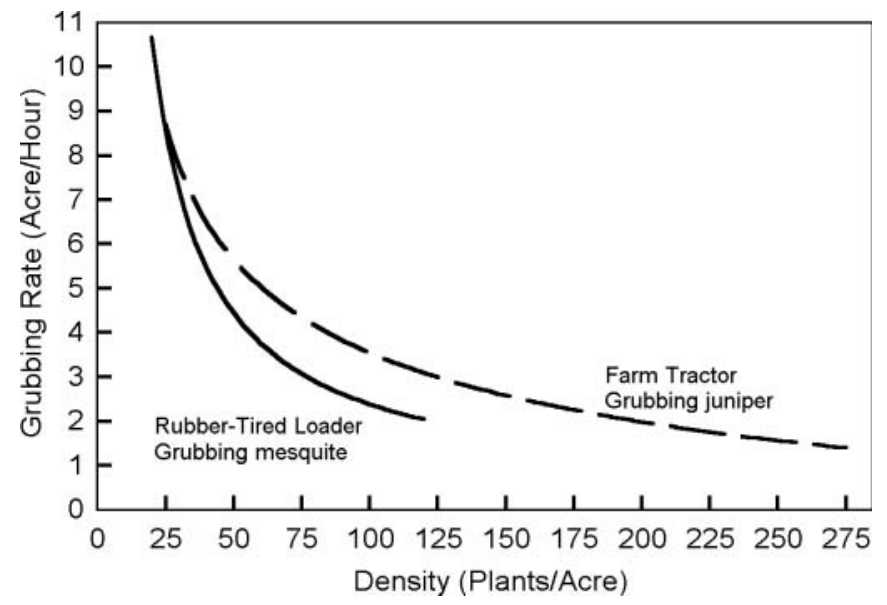

Figure 5. Performance curves for a wheeled loader grubbing mesquite 2-6 feet tall and for a farm tractor grubbing junipers $2-4$ feet tall.

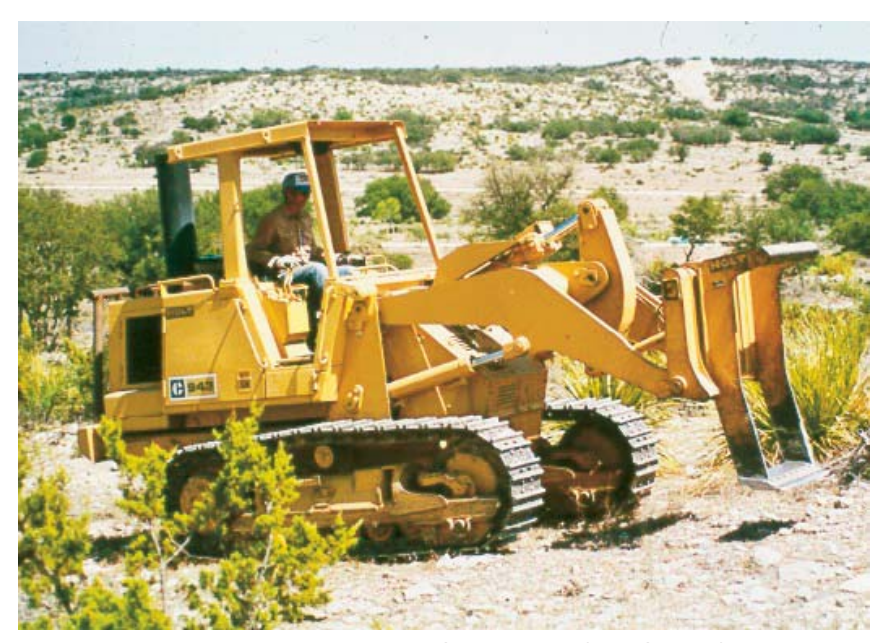

Figure 6. Track-loader grubber. Courtesy HOLT-CAT, San Antonio, Texas.

19 trees $\cdot$ acre $^{-1}$ but $42 \%$ less than the crawler at a density of 140 trees $\cdot$ acre $^{-1}$.

Farm tractors with front-end loaders are handy for grubbing juvenile trees (Fig. 3), and performance on small junipers (Juniperus spp.) is shown in Figure 5. Track-type loaders are also practical for grubbing because the forward location of the cab provides the operator with a good view of the grubbing blade and the small cleats on the track grouser allow minimum soil disturbance (Fig. 6).

\section{Three-Point-Hitch Grubbers}

A popular method for grubbing limited acreage of small trees uses a three-point-hitch grubber on the rear of a farm tractor. Some grubber styles require the tractor to drive over the tree first while others back the tractor to the tree and use the three-point hitch to lift the tree from the soil (Fig. 7). Grubbing trees by backing into them had an average rate of 155 mesquites $\cdot h^{-1},{ }^{5}$ while grubbing with frontmounted units on a crawler averaged 288 mesquites $\cdot \mathrm{h}^{-1}$ and 432 small junipers $\cdot h^{-1} \cdot 3,6$ 


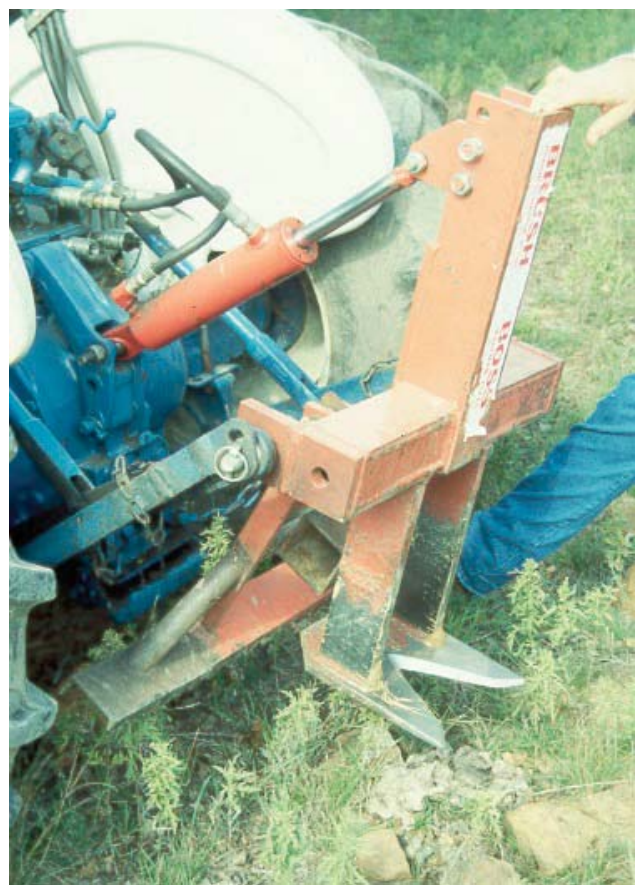

Figure 7. Three-point-hitch grubber. Courtesy Harold Wiedemann.

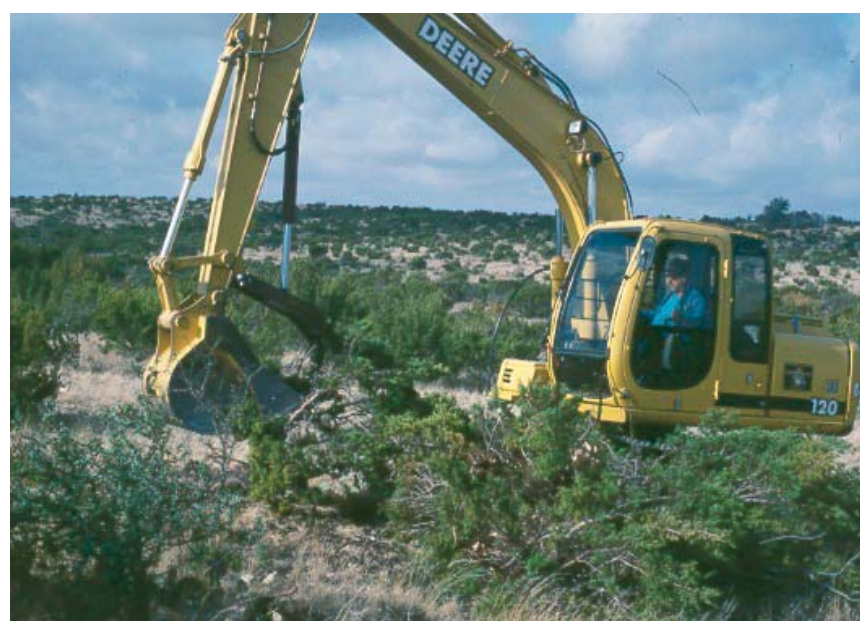

Figure 8. Excavator grubber. Courtesy Darrell Ueckert, San Angelo, Texas.

\section{Excavators}

The most recent addition to the list of grubbers is the excavator. Excavators are track-type, high-capacity backhoes that are front-mounted (Fig. 8). With the boom extended, they can work a 50 -foot swath while moving in a straight line. The bucket, equipped with rock-digging teeth and a two-prong clamshell clamp, is very effective for removing junipers from rocky soil and stacking them. A U-shaped grubbing blade can be used in place of the bucket. Observations by scientists estimate a grubbing rate of 200-500 trees $\cdot h^{-1}$. Excavators have air-conditioned cabs, "joystick" controls, and small cleats on the track grousers that enhance the their smooth operation.

\section{Skid-Steer Loaders}

Brush species, such as Ashe juniper (Juniperus ashei), which do not sprout from the roots, can be clipped above ground rather than uprooted below ground. Skid-steer loaders accomplish this using hydraulic shears (Fig. 9). Because of availability and low cost, they have become popular in sculpting landscapes. When shearing sprouting species (mesquite and redberry junipers [Juniperus pinchotii]), some contractors spray the stump with herbicide to reduce regrowth. ${ }^{7}$

\section{Selective Clearing}

Selective clearing implies that selected areas are cleared of all woody species, leaving a mosaic pattern or strips of cleared areas within the brushy landscape. The cleared areas should be seeded with native or introduced grasses and shrubs that meet multiple-use goals. Treatments can involve removing all aboveground growth, severing all roots at a given depth, or removing root systems from the soil. Clearing usually involves a combination of methods. The current machines used and their application are discussed in this section.

\section{Chains}

Ship-anchor chain pulled between two crawler tractors is widely used for tree felling because it can open an area quickly and is low in cost. Chains vary in length from 200 to 400 feet, weigh $40-75$ pounds $\cdot$ foot $^{-1}$, and are pulled in a U-shape. Chaining is used in moderately dense to dense stands of trees (trunk diameters $>3$ inches) and is most effective for uprooting when soil moisture is high. It is not effective on shrubs or small trees with limber stems. Effectiveness is short-lived because of regrowth, and chaining should be used in combination with other treatments for maximum effectiveness. In north Texas, mesquite is chained 2-3 years following aerial spraying, while in south

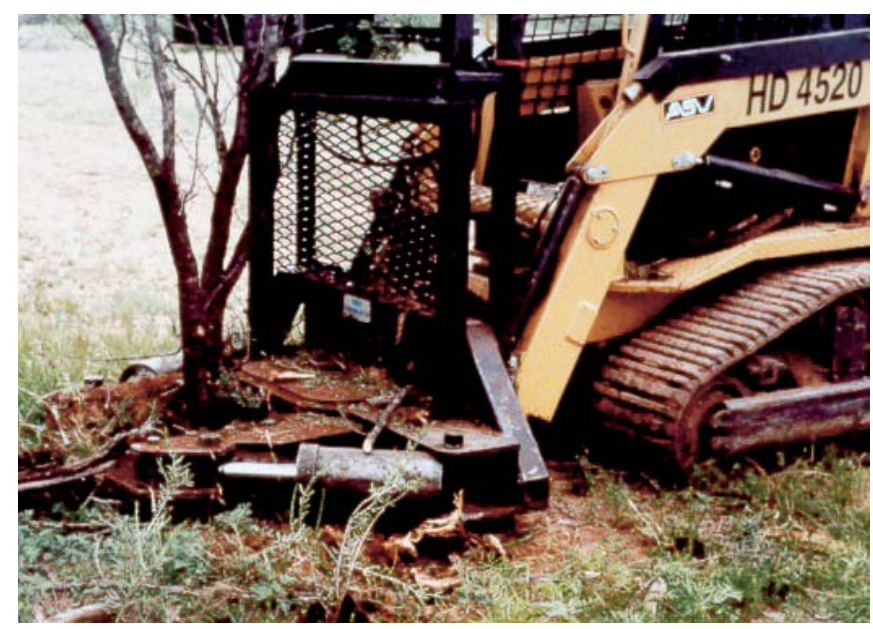

Figure 9. Skid-steer loader with shears. Courtesy Darrell Ueckert, San Angelo, Texas. 
Texas dense stands of mixed brush are chained and stacked prior to subsequent treatments. ${ }^{8}$

\section{Modified Chains}

Modification of an anchor chain can be made by adding a device to enhance the performance of the chain for brush manipulation and/or seedbed preparation. Examples follow.

Elevated chains. In individual tree tests, an elevated striking height reduced felling force by $67 \%$ compared to ground level striking on Ashe juniper in southern Oklahoma and by $84 \%$ on redberry juniper in north Texas. ${ }^{9,10}$ Elevated chaining is accomplished by attaching a rotating ball in the center of the chain pulled by two crawler tractors (Fig. 10). This one-way chaining method, if followed by prescribed burning, can achieve $98 \%$ eradication of Ashe juniper. The chain-burn strategy tested on redberry juniper, a sprouting species, did not improve eradication rates over chaining alone mainly because herbaceous fuel was uneven, and when burned it did not supply sufficient heat to burn the exposed stumps. ${ }^{11}$ A 4 -foot-diameter ball worked best in junipers that were 9-18 feet tall, and a 6-foot ball was more effective in trees that were $18-45$ feet tall. ${ }^{10}$

Disk-chain-diker. A unique tool developed mainly for seedbed preparation on debris-littered land, but also used for limited brush control, is the disk-chain-diker (Fig. 11). Although it was designed to follow rootplowing, it can also be used on undisturbed sites when shrubs are $<8$ feet tall. The disk-chain-diker tills, smoothes, and forms small basins in the soil all in one pass and is energy efficient. ${ }^{12} \mathrm{~A}$ disk chain is an anchor chain with disk blades welded to alternate chain links. Disking action occurs when the chain, with swivels attached to each end, rotates as it is pulled diagonally. A flexing roller holds the disk-chain gangs in place. The chain diker, which is attached to the rear of the roller, uses specially shaped blades welded to opposing sides of each link of a large anchor chain. As it is pulled over tilled land, the chain rotates and the blades leave a broadcast

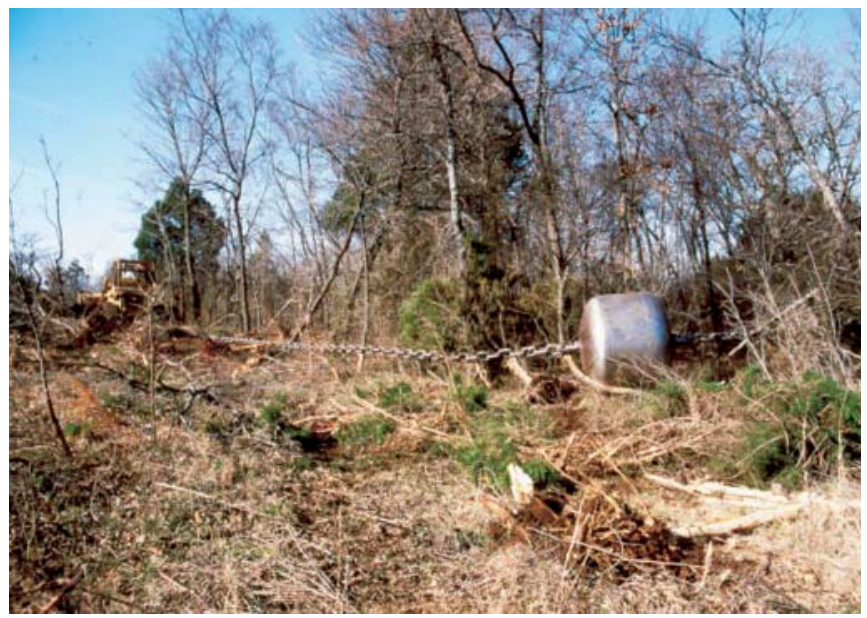

Figure 10. Elevated chain. Courtesy Harold Wiedemann.

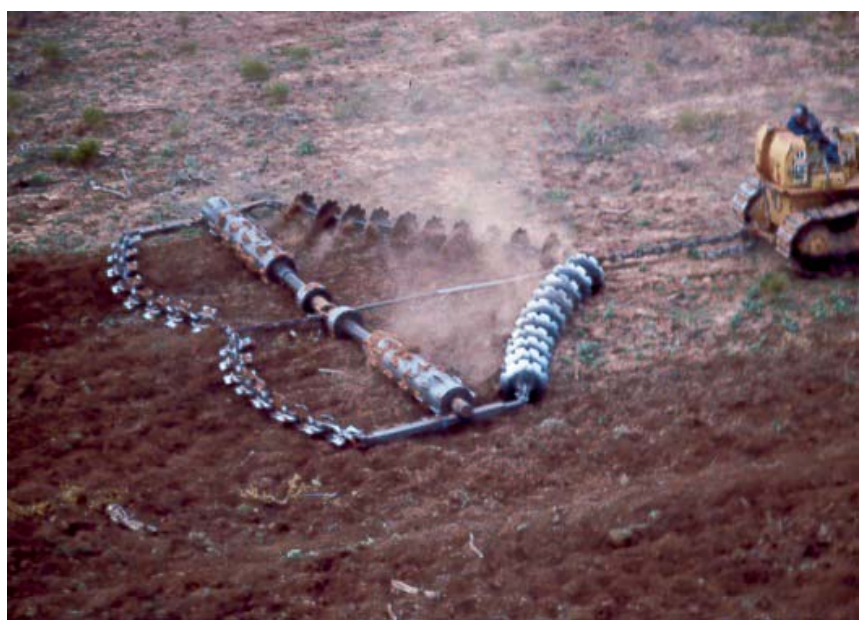

Figure 11. Disk-chain-diker. ${ }^{13}$

pattern of diamond-shaped basins 4 inches deep. Pulling requirements depend on the size of each component; a standard-sized unit requires a force of 515 pounds $\cdot$ blade $^{-1}$ and 20 blades are usually used. A 20-blade unit is 35 feet wide and requires a 165-200-horsepower crawler tractor for pulling. A detailed explanation of the unit is provided by Wiedemann. ${ }^{13}$

In seeding studies over a 3-year period, grass densities were increased 92\% when the disk-chain diker was used, compared to seedbeds prepared by using smooth chain in clay-loam soil. There was no significant difference in grass densities between seedbeds prepared by disk chaining or offset disking, but both were significantly higher than chaining alone. ${ }^{14}$ Basins prepared by the chain diker increased grass stands from $33 \%$ to 2.6 times the density of grass stands on non-diked areas when growing-season rainfall was $<20$ inches. ${ }^{15}$ Diking provided no advantage when growing-season rainfall was $>20$ inches. Since much of western Texas receives $<20$ inches of rainfall, it would be advantageous in many areas to include chain diking as part of seedbed preparation for rangeland seeding. Chain diking reduced runoff by $40 \%$ compared with non-diked treatments over a 3 -year period on a slope of $0.3 \%{ }^{16}$

\section{Rootplows}

A rootplow is a heavy-duty, V-shaped, 10-16-foot-wide horizontal blade pulled by a large crawler tractor at a depth of 12-14 inches (Fig. 12). This operation severs roots, preventing regrowth of nearly all brush species except those with shallow root systems such as whitebrush (Aloysia gratissima) and prickleypear cacti (Opuntia spp.). Chaining or raking following plowing helps to smooth the soil surface and remove sprouting species or stumps. Rootplows have been in use since the 1940s to clear dense stands of mesquite and other hard-to-kill brush species in preparation for seeding grasses or crops. ${ }^{8}$ The commercial rootplowing rate averages approximately 2 acres $\cdot \mathrm{h}^{-1}$. Sculpting densely 


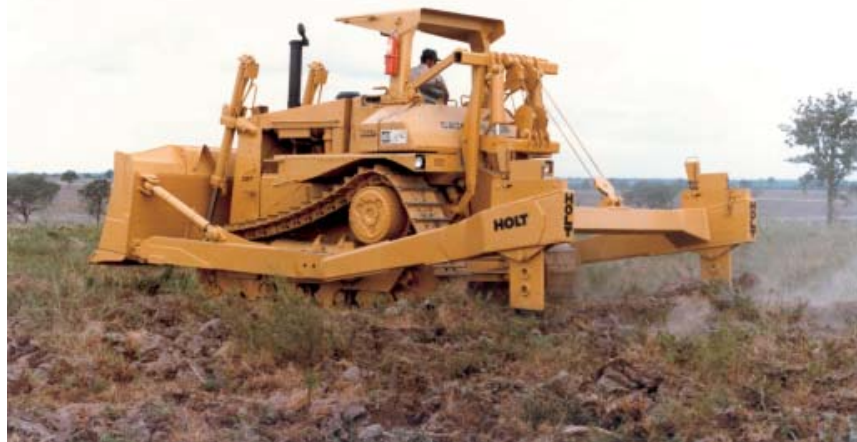

Figure 12. Rootplow. Courtesy HOLT-CAT, San Antonio, Texas.

brush-infested areas by selective plowing followed by seeding with plants favorable for wildlife habitat, grazing animals, and watershed management could enhance the multiple-use value of depleted rangeland on fertile soils. The most recent change in rootplows has been the development of regrowth plows.

\section{Regrowth Rootplows}

Holt Company of Texas (changed to HOLT CAT in 2002) has started manufacturing a line of regrowth plows (Fig. 13) and rakes for areas where brush regrowth occurs on land previously cleared with conventional rootplows. They are especially useful in coastal bermudagrass (Cynodon dactylon) pastures in parts of south Texas. Performance is best when tree-trunk diameters are $\leq 4$ inches. The plows resemble conventional rootplows but have been downsized to fit Caterpillar D-6 crawlers, rubber-tracked Challengers, or large farm tractors. ${ }^{17}$ These 10 -foot-wide units use quick hitches and are much more energy efficient and cost effective than conventional rootplows.

The regrowth root rake has been designed to operate in concert with the regrowth plow. These 14-foot-wide units remove roots from the soil and pile them along with any

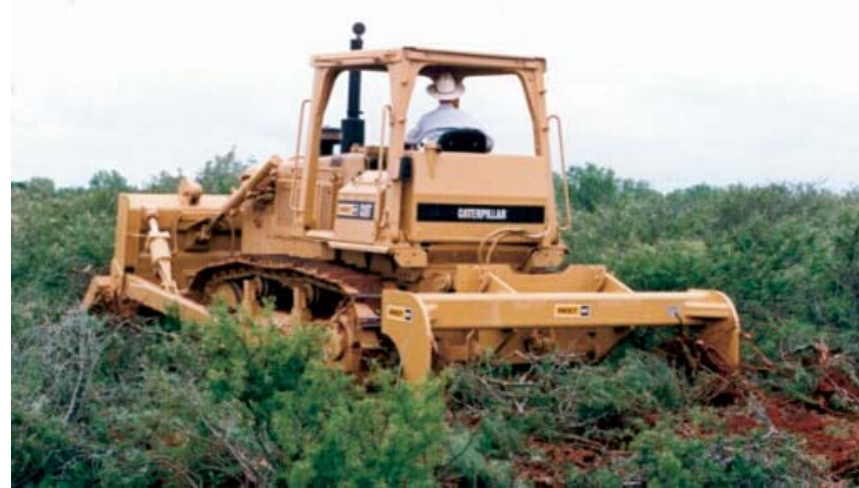

Figure 13. Regrowth plow. Courtesy HOLT-CAT, San Antonio, Texas. aboveground brush debris. ${ }^{17}$ They use the same quick hitch as the regrowth plows.

\section{Renovators/Aerators}

Roller chopping of brush has been accomplished using a large, rotating drum with a series of longitudinally mounted blades. A recent advancement in roller choppers is the use of small blades welded to the heavy drums in a staggered, cylindrical pattern; these units are called renovators or aerators (Fig. 14). ${ }^{18}$ The advantages of the renovators are that the small blades chop debris and form basins in the soil to capture and hold rainfall. In addition, the staggered, cylindrical blade pattern prevents the vibration caused by the longitudinal blade placement on standard-roller choppers. Renovators normally use 2 drums mounted on a frame similar to an offset disk and are pulled with a crawler tractor or specially equipped, rubber-tired tractor. The drum diameters vary from 18 to 42 inches and can be filled with water for added weight. Renovators are used in moderate to dense shrub-infested rangeland or pastures to remove the top growth of shrubs and to improve rainfall retention. Removal of the top growth produces a flush of regrowth. This is desirable for browsing animals when used on palatable brush species such as Bigelow shin oak (Quercus durandii var. breviloba) or guajillo (Acacia berlandieri). When seeding grass in combination with chopping, the basins enhance seedbed preparation. The rate of roller chopping on Bigelow shin oak averaged 5.3 acres $\cdot \mathrm{h}^{-1}$ using a 15 -foot-wide drum filled with water. ${ }^{19}$

\section{Disks}

Disks used on rangeland are the heavy-duty offset style. Blade diameters range from 24 to 36 inches and units are 8 to 12 feet in width. Disks with 36 -inch blades are used for brush control on undisturbed soil, while units with blade diameters $<30$ inches are used for seedbed preparation following rootplowing. Whitebrush was controlled by disking in the fall (13\% mortality) and then re-disking

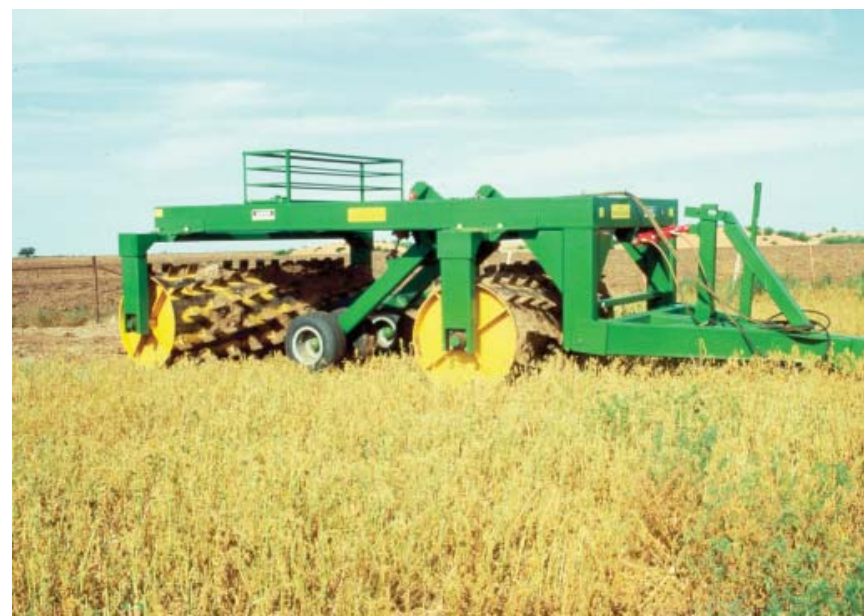

Figure 14. Renovator/aerator. Courtesy Harold Wiedemann. 


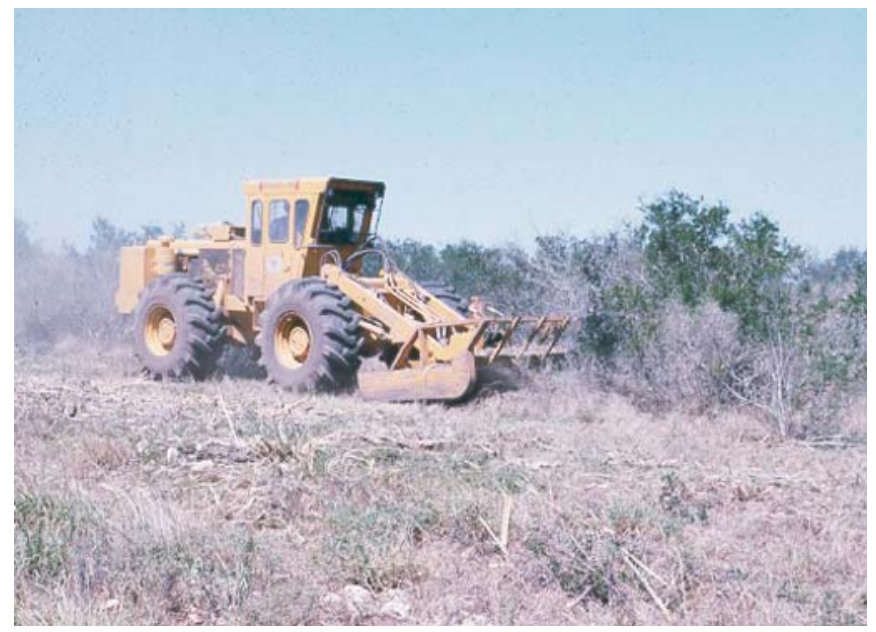

Figure 15. Self-propelled shredder. Courtesy Harold Wiedemann.

in the spring after the root crowns had sprouted (91\% mortality). ${ }^{20}$ Oats (Avena spp.) were seeded following fall disking and buffelgrass (Cenchrus ciliaris) was seeded following spring disking for livestock grazing. Seedbeds prepared by disking (24-inch blades) consistently produced better grass stands than did roller chopping or chaining on rootplowed sites at 9 locations in the Edwards Plateau and Rolling Plains. ${ }^{21}$ If excessive timber prevents the use of a disk, then a disk-chain-diker can be used.

\section{Shredders}

Brush shredders are patterned after pasture and crop shredders but are designed to withstand more strain. Their width is normally 7 feet, but selected units are 15 feet wide. Brush shredding is prone to mechanical failures and usually requires extensive modification of the farm tractor that pulls the unit. Modifications include foam filling of the tires or other approaches to prevent flats and mounting front and bellypan guards as well as a rear guard to protect the back of the operator from flying debris. Shredding brush leaves the plant height level, and this is aesthetically pleasing. Regrowth, however, is extensive following shredding of all sprouting shrubs. Mechanical downtime was $64 \%$ when shredding Bigelow shin oak with a standard 7-foot shredder in the Edwards Plateau. ${ }^{19}$ Shredders are more applicable for pasture weed control than brush control, but they can be used on brush over limited acreage.

Self-propelled shredders are constructed for brush mastication, and a Hydro-Ax unit was very effective in removing top-growth of Bigelow shin oak at a rate of 2.35 acres $\cdot h^{-1}$ (Fig. 15). However, they are expensive and not readily available.

\section{Summary}

Sculpting brush-dominated rangeland for multiple use has resulted in new opportunities for mechanical brush control methods. Managing brush infestations for better wildlife habitat, watershed management, and recreation enterprises often benefits from mechanical manipulation. This fact, coupled with new advancements in machines and methods in which they are used, has helped to establish mechanical brush control as a viable option in brush management. Costs are increasing in all phases of brush management, and currently, one may experience contractors adding fuel surcharges to their equipment costs.

\section{References}

1. Hamilton, W. T. 1985. Initiating IBMS. In: C. J. Scifres, W. T. Hamilton, J. R. Conner, J. M. Inglis, G. A. Rasmussen, R. P. Smith, J. W. Stuth, and T. G. Welch [eds.]. Integrated brush management systems for south Texas: development and implementation. Texas Agricultural Experiment Station Bulletin 1493:9-14.

2. Wiedemann, H. T., D. Rollins, D. N. Ueckert, and A. McGinty. 1999. Sculpting brush-dominated rangeland for multiple use. In: D. Eldridge and D. Freudenberger [eds.]. Proceedings of the VI International Rangeland Congress; 19-23 July 1999; Townsville, Queensland, Australia. p. 233234.

3. Wiedemann, H. T., B. T. Cross, and C. E. Fisher. 1977. Low-energy grubber for controlling brush. Transactions of the ASAE 20(2):210-214.

4. Wiedemann, H. T., and B. T. Cross. 1982. Performance of front-mounted grubber on rubber tired equipment. PR-3982:50-53. In: Texas Agricultural Experiment Station CPR-3968-4014.

5. McFarland, M. L., and D. N. Ueckert. 1982. Mesquite control: use of a three-point hitch mounted, hydraulically assisted grubber. PR-3981:48-50. In: Texas Agricultural Experiment Station. CPR-3968-4014.

6. Wiedemann, H. T., and B. T. Cross. 1981. Low-energy grubbing for control of junipers. Journal of Range Management 34(3):235-237.

7. McGinty, A., And D. N. Ueckert. 1997. Brush busters: how to beat mesquite. Texas Agricultural Extension Service \& Texas Agricultural Experiment Station. Leaflet L-5144.

8. Fisher, C. E., H. T. Wiedemann, C. H. Meadors, AND J. H. BRock. 1973. Mechanical control of mesquite. Texas Agricultural Experiment Station Research Monograph $1: 46-52$.

9. Wiedemann, H. T., And B. T. Cross. 1996a. Draft requirements to fell junipers. Journal of Range Management 49(2): 174-178.

10. Wiedemann, H. T., and B. T. Cross. 1996b. Draft requirements for tree felling by chaining. St. Joseph, MI: American Society of Agricultural Engineers. Paper No. 965003.12 p.

11. Ansley, R. J., H. T. Wiedemann, M. J. Castellano, and J. E. Slosser. 2006. Herbaceous restoration of juniper dominated grasslands with chaining and fire. Rangeland Ecology and Management 59:171-178.

12. Wiedemann, H. T., and B. T. Cross. 1994. Chain diker draft and power requirement. Transactions of the ASAE 37(2): 389-393.

13. Wiedemann, H. T. 1990. Disk-chain-diker implement selection and construction. Vernon, TX: Chillicothe-Vernon Agricultural Research and Extension Center. Center Technical Report No. 90-1. 19 p. 
14. Wiedemann, H. T., and B. T. Cross. 2000. Disk chain effects on seeded grass establishment. Journal of Range Management 53(1):62-67.

15. Wiedemann, H. T., and B. T. Cross. 2001. Chain diker effects on seeded grass establishment following disk chaining. Journal of Range Management 54(2):138-143.

16. Wiedemann, H. T., and L. E. Clark. 1996. Chain diking effects on runoff and winter wheat yield. Agronomy Journal 88:541-544.

17. Holt Company of Texas. 1997. Product literature. San Antonio, TX.

18. Lawson Cattle and Equipment, Inc. 1994. Pasture aerator product literature. Kissimmee, FL.

19. Wiedemann, H. T., C. H. Meadors, and C. E. Fisher. 1980. Bigelow shin oak control. Texas Agricultural Experiment Station. CPR-3665:28-29.

20. Wiedemann, H. T., and B. T. Cross. 1980. Evaluation of equipment for control of whitebrush. Texas Agricultural Experiment Station. CPR-3665:101-102.

21. Wiedemann, H. T., J. H. Brock, C. E. Fisher, and B. T. Cross. 1979. Seed metering and placement devices for rangeland seeder. Transactions of the ASAE 22(5):972-977.

22. Wiedemann, H. T. 1997. Factors to consider when sculpting brush: mechanical treatment options. In: D. Rollins, D. N. Ueckert, and C. G. Brown [eds.]. Proceedings of Brush Sculptors Symposium; 21-22 August, Uvalde, TX; and 17-18 September, Abilene, TX. San Angelo, TX: Texas Agricultural Extension Service. p. 88-95.

Author is Professor Emeritus, Texas AEMM University, 4000 Stony Creek Lane, College Station, TX 77845, h.wiedemann@ verizon.net.
Appendix. Common and scientific names of plants

\begin{tabular}{|c|c|}
\hline Common name & Scientific name \\
\hline Mesquite & $\begin{array}{l}\text { Prosopis glandulosa var. } \\
\text { glandulosa }\end{array}$ \\
\hline Junipers & Juniperus spp. \\
\hline Redberry juniper & Juniperus pinchotii \\
\hline Ashe juniper & Juniperus ashei \\
\hline Algerita & Berberis trifoliolata \\
\hline Huisache & Acacia smallii \\
\hline Twisted acacia & Acacia tortuosa \\
\hline Blackbrush & Acacia rigidula \\
\hline Whitebrush & Aloysia gratissima \\
\hline Catclaw & Acacia greggii \\
\hline Prickleypear cacti & Opuntia spp. \\
\hline Bigelow shin oak & Quercus durandii var. breviloba \\
\hline Guajillo & Acacia berlandieri \\
\hline Coastal bermudagrass & Cynodon dactylon \\
\hline Wheat & Triticum aestivum \\
\hline Oats & Avena spp. \\
\hline Buffelgrass & Cenchrus ciliaris \\
\hline
\end{tabular}

